April 2003 - NREL/CP-520-33953

\title{
A Barrier to Trap Filling in $\mathrm{Culn}_{1-\mathrm{x}} \mathrm{Ga}_{\mathrm{x}} \mathrm{Se}_{2}$
}

\section{Preprint}

D.L. Young, K. Ramanathan, M. Contreras, J. AbuShama, and R.S. Crandall

To be presented at the 2003 Materials Research Society Spring Meeting

San Francisco, California

April 21-25, 2003

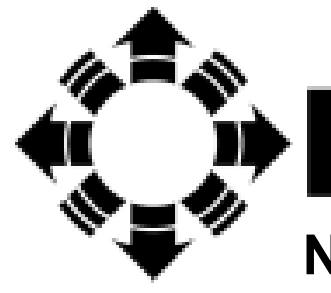

National Renewable Energy Laboratory

1617 Cole Boulevard

Golden, Colorado 80401-3393

NREL is a U.S. Department of Energy Laboratory

Operated by Midwest Research Institute $\bullet$ Battelle $\bullet$ Bechtel

Contract No. DE-AC36-99-G010337 


\section{NOTICE}

The submitted manuscript has been offered by an employee of the Midwest Research Institute (MRI), a contractor of the US Government under Contract No. DE-AC36-99G010337. Accordingly, the US Government and MRI retain a nonexclusive royalty-free license to publish or reproduce the published form of this contribution, or allow others to do so, for US Government purposes.

This report was prepared as an account of work sponsored by an agency of the United States government. Neither the United States government nor any agency thereof, nor any of their employees, makes any warranty, express or implied, or assumes any legal liability or responsibility for the accuracy, completeness, or usefulness of any information, apparatus, product, or process disclosed, or represents that its use would not infringe privately owned rights. Reference herein to any specific commercial product, process, or service by trade name, trademark, manufacturer, or otherwise does not necessarily constitute or imply its endorsement, recommendation, or favoring by the United States government or any agency thereof. The views and opinions of authors expressed herein do not necessarily state or reflect those of the United States government or any agency thereof.

Available electronically at http://www.osti.gov/bridge

Available for a processing fee to U.S. Department of Energy and its contractors, in paper, from:

U.S. Department of Energy

Office of Scientific and Technical Information

P.O. Box 62

Oak Ridge, TN 37831-0062

phone: 865.576.8401

fax: 865.576.5728

email: reports@adonis.osti.gov

Available for sale to the public, in paper, from:

U.S. Department of Commerce

National Technical Information Service

5285 Port Royal Road

Springfield, VA 22161

phone: 800.553 .6847

fax: 703.605.6900

email: orders@ntis.fedworld.gov

online ordering: http://www.ntis.gov/ordering.htm

Printed on paper containing at least $50 \%$ wastepaper, including $20 \%$ postconsumer waste 


\section{A Barrier to Trap Filling in $\mathrm{CuIn}_{1-\mathrm{x}} \mathrm{Ga}_{\mathrm{x}} \mathrm{Se}_{2}$}

David L. Young, Kannan Ramanathan, Miguel Contreras, Jehad AbuShama, Richard S. Crandall National Renewable Energy Laboratory, 1617 Cole Blvd., Golden, CO 80401

\section{ABSTRACT}

Voltage pulses of variable length were applied to $\mathrm{CuIn}_{1-\mathrm{x}} \mathrm{Ga}_{\mathrm{x}} \mathrm{Se}_{2} / \mathrm{CdS}(0<\mathrm{x}<1)$ junction solar cells. The resulting transient capacitance emission signal was recorded for several minutes. The amplitude of the capacitance emission signal increased linearly with the log of pulse time. These data do not follow the standard model for trap capture and emission of carriers. Instead they follow a simple electrostatic model based on electrostatic charging of traps.

\section{INTRODUCTION}

The $\mathrm{CuIn}_{1-\mathrm{x}} \mathrm{Ga}_{\mathrm{x}} \mathrm{Se}_{2}$ material system is one of the leading candidates for low-cost absorbers for thin-film solar cells achieving efficiencies over 19\% [1]. Device performance correlates with the density [2,3] and energy [4] of defect levels detected by capacitance techniques with a maximum efficiency occurring at $\mathrm{x} \sim 0.3$. Theoretical studies have assigned defect transition energy levels in the bandgap to specific crystalline defects[5]. However, metastabilities in the material system complicate the assignments of experimental and theoretical defect levels [6-10].

The nature of electronic traps is commonly studied using deep-level transient spectroscopy (DLTS) methods. DLTS approaches can determine defect energy levels relative to band edges (majority or minority trap), as well their trapping cross-section $(\sigma)[11,12]$. The charge emission-rate and $\sigma$ are important quantities for determining whether a defect functions as a recombination center or a shallow trap. This knowledge is especially important for photovoltaic (PV) materials because recombination limits the available photocurrent of the solar cell.

The most reliable method to determine $\sigma$ is to measure the density of trapped charge as a function of trap-filling pulse time $\left(t_{p}\right)$ in a junction device structure. The density of filled traps $\left(N_{f}\right)$ should increase linearly with time at short $t_{p}$ and finally saturate when charge is being emitted as fast as it is being captured. This process should obey the following equation [11]: $N_{f}(t)=N_{o}\left(1-e^{-\frac{t_{p}}{\tau_{c}}}\right)$, where $N_{o}$ is the saturated defect density and $\tau_{c}$ is the characteristic time containing $\sigma$.

This paper outlines a failed attempt to determine $\sigma$ in $\mathrm{CuIn}_{1-\mathrm{x}} \mathrm{Ga}_{\mathrm{x}} \mathrm{Se}_{2}$ using the above equation. Instead we find that $N_{s}(t)$ obeys the expression: $N_{s}(t)=A_{o} \ln \left(1+\frac{t_{p}}{t_{o}}\right)$, where $A_{o}$ is a constant and $t_{o}$ is a characteristic time. Similar behavior was observed in a-Si [13], GaAs [14], and $\mathrm{Ge}_{0.3} \mathrm{Si}_{0.7} / \mathrm{Si}$ [15]. A model [13] explaining these results is based on the realization that the traps are clustered, rather than uniformly distributed. Trap-filling charges these regions thus producing a potential barrier to further filling. 


\section{MATERIAL PREPARATION}

Thin films of p-type $\mathrm{CuIn}_{1-\mathrm{x}} \mathrm{Ga}_{\mathrm{x}} \mathrm{Se}_{2}$ were grown by co-evaporation using a "3-stage" process [16] onto molybdenum-coated, soda-lime glass substrates. Diodes were formed by depositing a thin film of n-type CdS by chemical-bath deposition onto the $\mathrm{CuIn}_{1-\mathrm{x}} \mathrm{Ga}_{\mathrm{x}} \mathrm{Se}_{2}$ layer. Devices were completed with an intrinsic $\mathrm{ZnO}$ layer and a conducting $\mathrm{ZnO}$ :Al layer, followed by $\mathrm{Ni} / \mathrm{Al}$ contact grids. Isolation of individual cells was achieved by mechanical scribing to define an active region of about $0.43 \mathrm{~cm}^{2}$.

\section{CAPACITANCE MEASUREMENT}

The junction of a CuIn ${ }_{1-\mathrm{x}} \mathrm{Ga}_{\mathrm{x}} \mathrm{Se}_{2} / \mathrm{CdS}$ solar cell device is thought to be $\mathrm{p}^{-} / \mathrm{n}^{+}$, thus confining the depletion region mainly to the $\mathrm{CuIn}_{1-\mathrm{x}} \mathrm{Ga}_{\mathrm{x}} \mathrm{Se}_{2}$ layer. To determine the charge trapped on metastable defects in the $\mathrm{CuIn}_{1-\mathrm{x}} \mathrm{Ga}_{\mathrm{x}} \mathrm{Se}_{2}$ material, we apply the familiar junctioncapacitance method [11]. The experimental procedure is as follows: First, a reverse bias of -0.5 $\mathrm{V}$ is applied for several hours to allow the device to come to a steady state. Next, a $-0.1 \mathrm{~V}$ bias pulse of varying length $\left(t_{p}=10^{-6}-10^{3} \mathrm{~s}\right)$ injects charge into the depletion width. Following the pulse, the $-0.5 \mathrm{~V}$ bias is immediately reapplied. Immediately following the bias pulse, the capacitance $(\mathrm{C}(\mathrm{t}))$ is recorded for five to seven decades of time until $\mathrm{C}(\mathrm{t})$ returns to its initial value, $C_{o}$. The voltage, acquisition triggering, and time are computer controlled. The capacitance is determined using a lock-in amplifier (Stanford Instruments Model 850) calibrated with a standard capacitor in place of the sample. Usually, the applied ac test signal is $10 \mathrm{kHz}$ at $0.03 \mathrm{~V}$ rms. The initial capacitance is recorded before each pulse, giving the baseline value $C_{o}$. Data were collected at a rate of 50,000 samples/second. Signal averaging and storing data only at logarithmic time intervals reduces the data set to a more manageable size. For the data presented here, devices were measured in the dark at room temperature. The capacitance change during the transient $\left(\Delta \mathrm{C}=\mathrm{C}(\mathrm{t})-\mathrm{C}_{\mathrm{o}}\right)$ is converted to trap density $\left(N_{s}\right)$ by using the relation [11] $N_{s}=$ $2 N_{o} \Delta C / C_{o}$, with $N_{o}$ the total defect density.

\section{DATA}

Figure 1 shows a series of $\Delta \mathrm{C}$ transients with $t_{p}$ ranging from $10^{-6}$ to $10^{3} \mathrm{~s}$ for an $\mathrm{x} \sim 0.3$ device. The dominant feature in Fig. 1 is the increasing amplitude of the majority-carrier [11] emission transient with increasing $t_{p}$. The data were fit with two stretched exponentials with characteristic time constants of milliseconds and seconds at room temperature. Figure 2 shows the initial amplitude of the change in capacitance following the filling pulse divided by the initial capacitance, $C_{o}$, versus the pulse time, $t_{p}$. The initial amplitude of the change in the capacitance was measured $10^{-3} \mathrm{~s}$ after the end of the pulse to

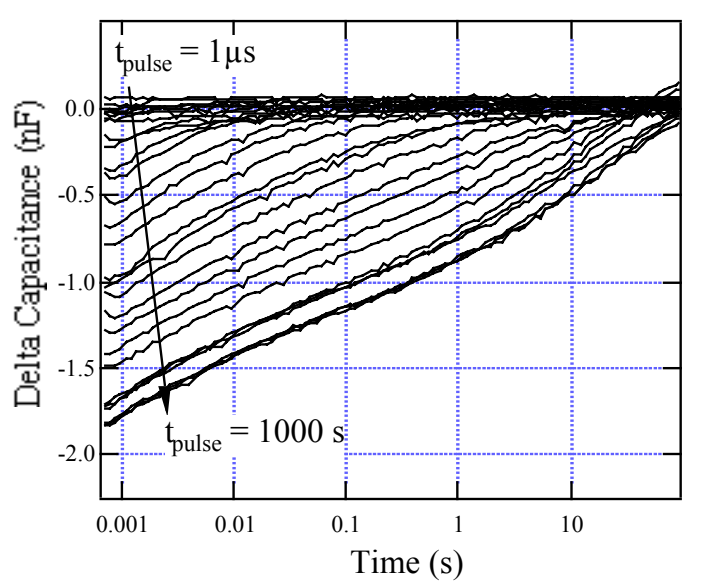

Figure 1. Change in capacitance vs. time following a voltage pulse. $t_{\text {pulse }}$ varies from $1 \mu$ s to $1000 \mathrm{~s}$, with three logarithmically separated pulse times per decade of time. 
ensure lock-in amplifier recovery. Note that each factor of 10 increase in $t_{p}$ results in the same linear increase in capacitance amplitude. The increasing amplitude with pulse width is likely due to partial filling of the states with short pulse times. An apparent saturation of the signal occurs only for pulse times $t_{p}>10^{2} \mathrm{~s}$. Samples with $\mathrm{x}=$ 1,0 also show the $\log \left(t_{p}\right)$ dependence and apparent saturation behavior.

\section{THEORY}

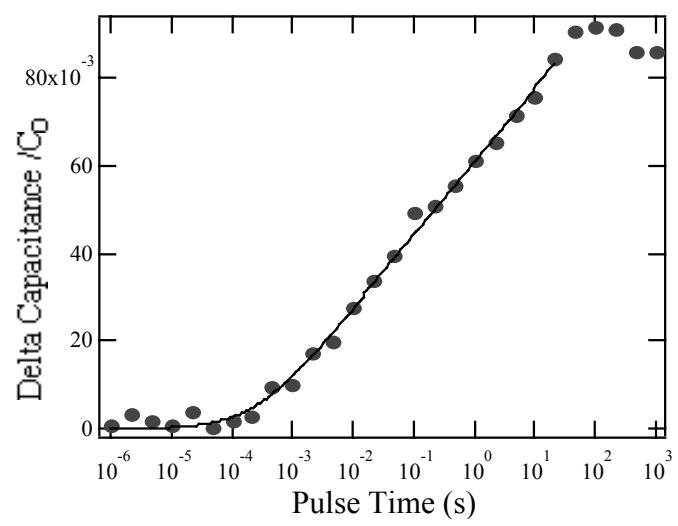

Figure 2. $\Delta \mathrm{C} / \mathrm{C}_{\mathrm{o}}$ vs voltage pulse time. Circles are data points. The dark line is a fit to the data by equation 3 .

Following the work with a-Si [13] we assume the $\mathrm{CuIn} \mathrm{In}_{1-\mathrm{x}} \mathrm{Ga}_{\mathrm{x}} \mathrm{Se}_{2}$ material is inhomogeneous and filled with a random distribution of clustered traps. During the filling pulse, these traps acquire charge that increases with time. However, a Coulomb repulsion energy barrier builds over time, which hinders further trapping of charge. The potential of the trap is $\Phi$ $=N_{s} f$, where $N_{s}$ is the density of the carriers captured by the trap during the filling time, $t_{\mathrm{p}}$, and $f$ is a model-dependent coupling factor. $N_{s}$ varies with time for the filling of traps according to the first-order rate equation,

$$
\frac{d N_{s}}{d t}=n W_{\text {filling }}\left\langle N_{o}-N_{s}(t)\right\rangle
$$

where $n$ in the density of valence-band holes, $N_{o}$ is the total density of traps, and $W_{\text {filling }}$ is the filling probability having units of $\mathrm{cm}^{3} / \mathrm{s}$ and related to $\sigma$ via $W_{\text {filling }}=\sigma<\mathrm{v}_{T}>$, where $<\mathrm{v}_{T}>$ is the average thermal velocity of the carriers. The equilibrium defect levels, $N_{o}$, were measured by drive-level capacitance profiling [17] at the equilibrium bias used for the voltage pulse experiments $(-0.5 \mathrm{~V})$. If $n$ is a constant, eqn (1) has a trivial solution. However, as the traps become charged, $n$ is reduced in the vicinity of the charge distribution. If we assume the carrier density follows a Boltzmann distribution with $n_{o}$ the carrier density far from the trap, then eqn (1) reduces to

$$
\frac{d N_{s}(t)}{d t} \approx W_{\text {filling }} N_{o} n_{o} \exp \left(-\frac{e \Phi}{k_{B} T}\right)=W_{\text {filing }} N_{o} n_{o} \exp \left(\frac{-e N_{s} f}{k_{B} T}\right)
$$

where $k_{B}$ is Boltzmann's constant and $T$ is absolute temperature. Forcing all traps to be empty at $t=0\left(N_{S}(0)=0\right)$ and relating $N_{S}(t)$ to capacitance via the depletion-width approximation $[11,18]$ gives

$$
\frac{\Delta C}{C_{o}}=A_{o} \operatorname{Ln}\left(1+\frac{t_{p}}{t_{o}}\right)
$$


with constants

$$
A_{o}=\frac{k_{B} T}{2 N_{o} \text { ef }} \quad \text { and } \quad t_{o}=\frac{2 A_{o}}{n_{o} W_{\text {filling }}} .
$$

\section{DISCUSSION}

Figure 2 shows the fit to the data by eqn. (3). Similar excellent fits are common for both

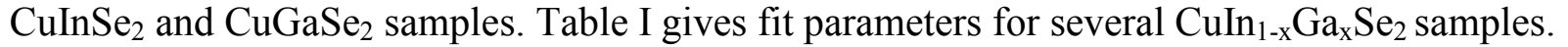
Clearly, the amplitude of the change in capacitance varies as the natural log of the voltage pulse length. This same relationship was found by Crandall on a-Si solar cells [13] and by Wosinski et al. [14] in plastically deformed GaAs, but without the saturation in signal at long pulse times. Grillot et al. [15] found that $\mathrm{Ge}_{0.3} \mathrm{Si}_{0.7} / \mathrm{Si}$ heterostructures followed eqn. (3), with signal saturation strongly dependent on sample preparation. However, this trend is in clear contrast to similar data taken on Ge bicrystals, where the amplitude of the change in capacitance varied according to a power law of $t_{p}$, and did saturate at long pulse times [19]. It is interesting to note the greater similarity of our polycrystalline material data to that of the amorphous material and the deformed GaAs, as opposed to the Ge bicrystal. Perhaps a comparison of the defects in each of these materials to those in $\mathrm{CuIn}_{1-\mathrm{x}} \mathrm{Ga}_{\mathrm{x}} \mathrm{Se}_{2}$ [5] will shed light on the origin of the observed traps in this material system.

Table I. Fit and calculated parameters

\begin{tabular}{|c|c|c|c|c|c|c|}
\hline $\begin{array}{c}\text { Sample } \\
\left(\mathrm{CuIn}_{1-\mathrm{x}} \mathrm{Ga}_{\mathrm{x}} \mathrm{Se}_{2}\right)\end{array}$ & $\mathrm{A}_{\mathrm{o}}$ & $\mathrm{t}_{\mathrm{o}}$ & $\begin{array}{c}\mathrm{N}_{\mathrm{o}}\left(\mathrm{cm}^{-3}\right) \\
(-0.5 \mathrm{~V})\end{array}$ & $\begin{array}{c}\text { Radius } \\
(\mathrm{nm})\end{array}$ & $\begin{array}{c}\mathrm{n}_{\mathrm{o}} \\
\left(\mathrm{cm}^{-3}\right)\end{array}$ & $\begin{array}{c}\sigma \\
\left(\mathrm{cm}^{2}\right)\end{array}$ \\
\hline $\mathrm{S} 2051(\mathrm{x}=0.3)$ & $7.34 \times 10^{-3}$ & $3.86 \times 10^{-4}$ & $5 \times 10^{16}$ & 18 & $5 \times 10^{16}$ & $8 \times 10^{-23}$ \\
\hline $\mathrm{S} 2038(\mathrm{x}=0.3)$ & $9.68 \times 10^{-3}$ & $9.89 \times 10^{-3}$ & $4.2 \times 10^{15}$ & 55 & $4 \times 10^{14}$ & $4 \times 10^{-22}$ \\
\hline $\mathrm{Sc} 1391(\mathrm{x}=1.0)$ & $7.28 \times 10^{-3}$ & $2.36 \times 10^{-4}$ & $2.2 \times 10^{17}$ & 9 & $8 \times 10^{16}$ & $7 \times 10^{-23}$ \\
\hline $\mathrm{S} 2044(\mathrm{x}=0.0)$ & $1.70 \times 10^{-2}$ & $6.81 \times 10^{-3}$ & $1.57 \times 10^{16}$ & 22 & $2 \times 10^{16}$ & $3 \times 10^{-23}$ \\
\hline
\end{tabular}

If we assume the charging centers are spherical (as opposed to say, parallel cylinders), then the coupling factor becomes, $f=e R^{2} / 3 \varepsilon$, where $e$ is the elemental charge, $R$ is the radius of the sphere, and $\varepsilon$ is the dielectric constant of the material. With $f$ so defined the constant $\mathrm{A}_{o}$ may be related to the radius of the spherical traps. Table I gives the calculated radii of these hypothetical traps. The calculated radial dimensions of the hypothetical charging spheres are of the same order of magnitude as the smallest polycrystalline "grains" seen by Romero et al. using scanning electron microscopy images and by spectrally resolved cathodoluminescence data [20]. Their data show a shallow defect concentrated on the outer "skin" of the grains. This dimensional coincidence may imply that the charging is taking place at the surface of the grains. Single-crystal samples need to be tested to verify this.

Capture cross-sections for the observed traps may be calculated from the fit parameters $A_{o}$ and $t_{o}\left(\left(\right.\right.$ eqn (4)) and the definition of $W_{\text {filling }}$ given earlier. Table I gives the calculated crosssections of the samples. Obviously, they are surprisingly small, but do agree somewhat with DLTS data [21]. Perhaps either the meaning of cross-section for this trap needs to be reconsidered or the small cross-sections for the capture of carriers on these traps may imply they 
are benign in terms of device performance. Alternatively, the small, calculated cross-section could be due to a repulsive barrier superimposed onto the charging barrier from the traps [22]. More detailed study of this effect is ongoing.

Finally, the data of Figs. 1 and 2 have significant implications for the applicability of the traditional DLTS technique for the $\mathrm{CuIn}_{1-\mathrm{x}} \mathrm{Ga}_{\mathrm{x}} \mathrm{Se}_{2}$ material system. The decays of Fig. 1 are neither exponential nor do they represent a single defect. A single exponential decay is a main assumption in DLTS theory. The data of Fig. 2 imply that the traps are not saturated during typical DLTS pulse lengths. Nonsaturation of traps during a DLTS "filling pulse" gives erroneous trap densities.

\section{REFERENCES}

K. Ramanathan et al. Accepted for publication, Progress in Photovoltaics, 2003.

G. Hanna, A. Jasenek, U. Rau, and H. W. Schock, Thin Solid Films 387, 71-73 (2001).

R. Herberholz, M. Igalson, and H. W. Schock, J. Appl. Phys. 83, 318-325 (1998).

J. T. Heath, J. D. Cohen, W. N. Shafaman, D. X. Liao, and A. A. Rockett, Appl. Phys. Lett. 80, 4540-4542 (2002).

S. B. Zhang, S.-H. Wei, and A. Zunger, Physical Review B 57, 9642-9656 (1998).

M. Igalson and P. Zabierowski, Thin Solid Films 361-362, 371-377 (2000).

V. Nadazdy, M. Yakushev, E. H. Djebbar, A. E. Hill, and R. D. Tomlinson, J. Appl. Phys. 84, 4322-4326 (1998).

U. Rau, M. Schmitt, and J. Parisi, Appl. Phys. Lett. 73, 223-225 (1998).

A. E. Delahoy, A. Ruppert, and M. Contreras, Thin Solid Films 361-362, 140-144 (2000).

J. Abushama, S. Johnston, R. Ahrenkiel, and R. Noufi, in Deep level transient spectroscopy and capacitance-voltage measurements of $\mathrm{Cu}(\mathrm{In}, \mathrm{Ga}) \mathrm{Se}_{2}$, New Orleans, LA, 2002 (IEEE), p. 740-743.

D. V. Lang, in Thermally Stimulated Relaxation in Solids, edited by P. Braunlich (Springer-Verlag, New

York, 1979).

D. V. Lang, J. Appl. Phys. 45, 3014-3022 (1974).

R. S. Crandall, Journal of Electronic Materials 9, 713-726 (1980).

T. Wosinski, A. Morawski, and T. Figielski, Appl. Phys. A 30, 233-235 (1983).

P. N. Grillot, S. A. Ringel, E. A. Fitzgerald, G. P. Watson, and Y. H. Xie, J. Appl. Phys. 77, 3248-3256

(1995).

U.S. Patent No. 5,436,204 (1995).

C. E. Michelson, A. V. Gelatos, and J. D. Cohen, Appl. Phys. Lett. 47, $412-414$ (1985).

G. L. Miller, D. V. Lang, and L. C. Kimerling, in Annual Review of Materials Science; Vol. 7, edited by R.

A. Huggins, R. H. Bube, and R. W. Roberts (Annual Reviews, Palo Alto, 1977), p. 377.

A. Broniatowski and J.-C. Bourgoin, Physical Review Letters 48, 424-427 (1982).

M. J. Romero, K. Ramanathan, M. A. Contreras, M. M. Al-Jassim, J. Abushama, and R. Noufi, in Mesoscopic fluctuation in the distribution of electronic defects near the surface layer of $\mathrm{Cu}(\mathrm{In}, \mathrm{Ga}) \mathrm{Se}_{2}$, Solar Program Review Meeting, Denver, CO, 2003 (U.S. Department of Energy).

J. A. AbuShama, Thesis, Colorado School of Mines, 2003.

R. S. Crandall, Spring MRS Symp. B, B2.5 (2003). 


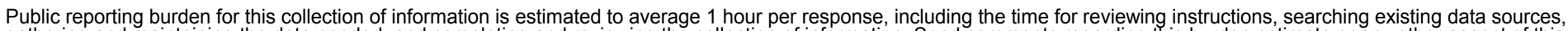

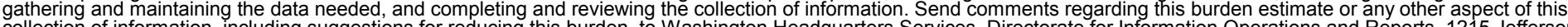

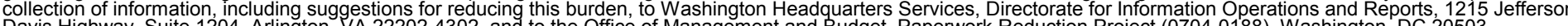
Davis Highway, Suite 1204, Arlington, VA 22202-4302, and to the Office of Management and Budget, Paperwork Reduction Project (0704-0188), Washington, DC 20503.
1. AGENCY USE ONLY (Leave blank)
2. REPORT DATE April 2003
3. REPORT TYPE AND DATES COVERED Conference paper

4. TITLE AND SUBTITLE

A Barrier to Trap Filling in Culn ${ }_{1-x} \mathrm{Ga}_{x} \mathrm{Se}_{2}$ : Preprint

5. FUNDING NUMBERS PVP34901

6. AUTHOR(S)

D.L. Young, K. Ramanathan, M. Contreras, J. AbuShama, and R.S. Crandall

7. PERFORMING ORGANIZATION NAME(S) AND ADDRESS(ES)

National Renewable Energy Laboratory

1617 Cole Blvd.

8. PERFORMING ORGANIZATION REPORT NUMBER

NREL/CP-520-33953

Golden, CO 80401-3393

9. SPONSORING/MONITORING AGENCY NAME(S) AND ADDRESS(ES)

10. SPONSORING/MONITORING AGENCY REPORT NUMBER

11. SUPPLEMENTARY NOTES

12a. DISTRIBUTION/AVAILABILITY STATEMENT

National Technical Information Service

12b. DISTRIBUTION CODE

U.S. Department of Commerce

5285 Port Royal Road

Springfield, VA 22161

13. ABSTRACT (Maximum 200 words): Voltage pulses of variable length were applied to Culn ${ }_{1-\mathrm{x}} \mathrm{Ga}_{\mathrm{x}} \mathrm{Se}_{2} / \mathrm{CdS}(0<\mathrm{x}<1)$ junction solar cells. The resulting transient capacitance emission signal was recorded for several minutes. The amplitude of the capacitance emission signal increased linearly with the log of pulse time. These data do not follow the standard model for trap capture and emission of carriers. Instead they follow a simple electrostatic model based on electrostatic charging of traps.

14. SUBJECT TERMS: PV; voltage pulses; trap filling; deep-level transient spectroscopy $\quad 15$. NUMBER OF PAGES

(DLTS); chemical-bath deposition; junction-capacitance; spectrally resolved cathodoluminescence (SRCL);

16. PRICE CODE

17. SECURITY CLASSIFICATION OF REPORT Unclassified
18. SECURITY CLASSIFICATION OF THIS PAGE Unclassified
19. SECURITY CLASSIFICATION OF ABSTRACT Unclassified
20. LIMITATION OF ABSTRACT

UL 